\title{
CONSUMPTION PATTERNS OF RURAL COMMUNITY: A STUDY OF FIVE FOOD COMMODITIES EXPENDITURE IN CENTRAL SULAWESI
}

\author{
Ichwan Mohamad ${ }^{\star}$, Moelyono Mauled \\ Faculty of Economics and Business, Tadulako University, Indonesia \\ Yusuf Dahlia \\ Master's Study Program of Rural Development, Tadulako University, Indonesia \\ *E-mail: mitandju@yahoo.com
}

\begin{abstract}
Developments in rural areas since they have received funding for development tend to change household consumption patterns; therefore the attention to rural consumption patterns is a good topic for scientific research. This research aims to recognize the consumption patterns of five dominant food commodities by using a descriptive analysis of 6.178 households obtained through the national secondary data of the 2017 National Social and Economic Survey. Identified: (1) rice; (2) cigarettes; (3) mixed rice; (4) fish; and (5) sugar, which is the five biggest consumption commodities in rural households and it is found that consumption tended to increase along with increased income.
\end{abstract}

\section{KEY WORDS}

Consumption patterns, food, elasticity, expenditure, income.

Population growth over the past two decades from 1990 to 2010 experienced a relatively rapid growth rate, creating an increase in serious efforts in maintaining the availability of food for living needs and non-food for other productive activities. Efforts to maintain the availability of primary, secondary and tertiary needs contribute to realizing public welfare, but on the contrary, it will mark the failure to achieve prosperity.

In Indonesia, food consumption expenditure is relatively higher compared to non-food consumption expenditure marked by the proportion of consumption expenditure of rice, other foods, and processed foods reaching 65 percent so that the stability of food prices plays a role in maintaining people's purchasing power. The uncontrolled prices of all three have an impact on the ability to consume most of the population is strengthened by the Central Statistics Agency (2017) notes that the contribution of food prices to food inflation increases by around 5 percent. In addition, rice as an essential food plays an important role in calculating the consumer price index, so that changes in prices determine the movement of food prices and the escalation of inflation. The increase in food prices has an impact on the ability of consumption of the poor triggered by the dominant role of prices in reducing the level of welfare of poor households.

Poverty (Nicholson, 2005) is inseparable from the ability to meet basic needs both food and non-food. Its identification is simplified by assessing the proportion of food expenditure to all household expenses as reflected in Engel's law which finds a common phenomenon when income increases, the proportion of income spent on food purchases decreases, even if the actual expenditure for food increases the smaller of food expenditure, so the more the high welfare of a nation's people in other terms as food income elasticity is always between 0 and 1. The Province of Central Sulawesi through the Central Statistics Agency (2017) notes that during 2008-2010 faced the same phenomenon that the proportion of per capita expenditure by the public more than 50 percent was used for food consumption. This phenomenon initiated the need for a scientific study of consumption patterns in rural communities.

The consumption patterns of society that tend to change from time to time also reflect changes in consumption patterns between urban and rural areas. Such change is very 
dependent on the environment and the availability of resources, tastes, and income. Changes in consumption patterns are also created through public awareness about food and nutrition and life changes so that the management of resources and their distribution plays a role in maintaining community affordability.

Maintaining distribution as a necessary condition in the effort to adequately consume food should be supported by efforts to encourage income to ensure the fulfillment of sufficient requirements so that food consumption is evenly distributed among all groups of people. The relationship between income and consumption expenditure has long been developed and is known as Engel's Law a general phenomenon that the percentage of expenditure for food consumption decreases with increasing income (Salvatore D. 2006), so it is concluded that there is a reversal of the relationship between income and the proportion of food expenditure. Therefore, the population consumption pattern can function as a marker regarding the level of welfare of the population. The higher welfare of the population is marked by an increase in income facing the proportion of food consumption expenditure which tends to decrease. On the other hand, the proportion of food consumption expenditure which is relatively high indicates that the level of welfare of the population is still low. So it can be said that differences in people's consumption patterns are a sign of differences in income.

\section{LITERATURE REVIEW}

The relationship between consumption patterns and income is still an interesting study, especially a study of the types of food and non-food commodities that are dominant in household consumption. Food consumption patterns in Indonesia have been revealed through several studies conducted by Marpaung (2006), Sayekti (2009), Purwaningsih et al (2010). While research on dipping consumption patterns in rural areas has been carried out by Ahmad, A. et al (2017). The various studies consistently use the household analysis unit but do not examine specifically the dominant consumption in rural communities.

In principle, research into consumption patterns has been developing for a long time. Some of them recognize the consumption of certain groups of people according to economic conditions, such as consumption in the middle class in China through the data of the Chinese General Social Survey (Zhu, Di, 2011). This effort reviews consumption patterns that contain the taste and material culture faced by society in the presence of globalization. Other developments are still consistent with the variables applied in Engel's Law, looking more specifically at rural households by applying the elasticity of consumption expenditure as a proxy for the elasticity of quantity income requested. In addition, research is also developed to examine the determinants of consumption expenditure among rural populations (Sethi, N, and Pradhan, HK, 2012; M. Fasoranti, 2014).

Other development topics lead to the study of consumption patterns that are associated with the economic status of certain populations, such as the elderly, and have even touched on rural communities (Lee, S., et al., 2014; Ahmad, A.et al., 2017). Although the research has developed a different study, it still rests on the basic concepts built by Ernest Engel. The difference in their studies is the effort to explore research objectives based on different approaches, namely using quantitative and qualitative research paradigms. Efforts to find the link between consumption patterns and the environment are part of the development of further research. Based on various considerations, including economic growth accompanied by an increase in population and globalization has resulted in structural changes in consumption patterns throughout the world. The efforts to estimate the relationship between changes in consumption patterns and environmental impacts are even more specific on emissions (Sherma et al. 2018; Caron and Fally, 2018).

Various empirical results about consumption patterns - identified through consumption expenditure have reinforced the role of income in consumption patterns. The relationship between income and consumption is firm as stated in the concept of marginal propensity to consume / MPC by Keynes, the relationship between the two is observed through their respective changes but Keynes expressly reveals that the increase in consumption is not as 
large as the increase in income. The relationship between the two is also emphasized through Engel's Law in another form that uses income elasticity for food elasticity of value between 0 and 1 including meaning and emphasis on the proportion of food consumption expenditure decreases when there tends to be an increase in income.

Previous research has not used empirical data to recognize the propensity to consume (MPC) both food and non-food. Including the unexplained components of food consumption and non-food consumption that have not been revealed in rural households. The difference in population consumption patterns in rural areas as a result of differences in household income is a new challenge in further study, including adding research into the consumption patterns of rural households in Indonesia. This research is conceived to recognize the dominant propensity to consume and consume in households in rural Central Sulawesi.

Rural development, which has tended to accelerate development over the past three years as a result of development commitments in rural areas, has led to fundamental changes in rural communities. Strengthening the allegation that consumption patterns have changed along with the development of the village so that various previous research findings are no longer relevant to reflect the consumption patterns of rural communities in the current conditions. Although it is limited to the Central Sulawesi region, research on the consumption patterns of people in rural areas needs to be carried out by directing the research objective in the form of knowing the five largest types of food commodities in rural households in Central Sulawesi.

\section{METHODS OF RESEARCH}

The consumption patterns of the five most types of food commodities are identified by two sequential stages. The first stage collects all household expenditures consisting of food and non-food consumption expenditure contained in a set of national secondary data of the 2017 National Social and Economic Survey. Then sort the amount of expenditure per household from the largest to the smallest to get the ten most expenses in the household, including food consumption expenditure. The second stage, after the identification of the most food commodities, is then determined the five most food consumption commodities as household food consumption commodities in rural areas which are the center of attention for consumption patterns. Based on this method, this research is exploratory for cross-section data (Sugiyono, 2011; Bungin B., 2017). Identifying household consumption expenditure as the total household consumption expenditure used to explain the relationship between income and consumption of the five most types of food commodities, therefore, this research is identified as descriptive research (Arikunto S., 2013; Anshori M. and Iswati S., 2017).

Efforts to determine the consumption patterns of five types of food commodities are carried out by describing the five most food commodities that have been determined. Most commodities are based on the number of households consuming and the amount of food commodity expenditure available in national secondary data. Based on national secondary data, it was identified that the number of rural households in Central Sulawesi was 4.832 or equal to 78 percent of the 6.178 survey households studied to produce the most food consumption.

The consumption pattern is explained based on the tendency between consumption expenditure of each commodity and income through the grouping of expenditure and grouping of household income. Consumption expenditure and household income are formed in five groups, namely the first group consisting of 20 percent of households with the lowest consumption expenditure and income, to the fifth group consisting of 20 percent of the households with the highest consumption and income expenditure.

\section{RESULTS AND DISCUSSION}

This research identified the most food commodities, namely: (1) rice; (2) granulated sugar; (3) cayenne pepper; (4) cake; (5) fish; (6) cigarettes; (7) mixed rice; and (8) beverage. 
Furthermore, five commodities with the most expenditure for one month were found, consisting of (1) rice; (2) cigarettes; (3) mixed rice; (4) fish; and (5) granulated sugar.

The number of households that have positive rice expenditure that is, households with more expensive rice expenditure as many as 4.771 (98.7\%) of 4.832 . Group them into five groups of households with the first 20 percent as the lowest rice expenditure group to the fifth 20 percent as the highest rice expenditure group. The same grouping is also carried out on household income, namely the first 20 percent as the lowest income group to the fifth 20 percent as the highest income group.

Identifying based on the calculation of the mean of expenditure and income, it was found that rice consumption expenditure increased with increasing expenditure indicating rice consumption tended to increase along with income increase rice consumption increased when income was higher as revealed through Figure 1 which links between two income groups and five expenditure groups rice consumption. Two income groups, namely the lowest and highest income groups coupled with the five groups of rice consumption expenditure, identified the consumption of certain patterned rice consumption.

In the lowest income group, the number of households is dominated by those with the smallest consumption expenditure, but the number of the lowest income households tends to decrease along with more consumption expenditure. On the contrary, in the highest income group, the number of households is dominated by those with the highest expenditure and tends to decrease with lower consumption expenditure. In the third group a total of 360 households that have rice consumption expenditure of IDR 55.350.00 - IDR 67.450.00, consisting of more (almost 62\%) the number of households with the highest income compared to the number of households with the lowest income. Furthermore, in the group of higher (fourth and fifth) rice consumption, increasingly dominated (70\% and $95 \%)$ by the number of households with the highest income. The sign that rice is as the main commodity and in certain income groups will be more sensitive to income. This finding is consistent with Recalis RH and Salas J.M.I (2008); Sethi N. and Pradhan H.K. (2012); M. Fasoranti (2014); and Ahmad, A. et al (2017).

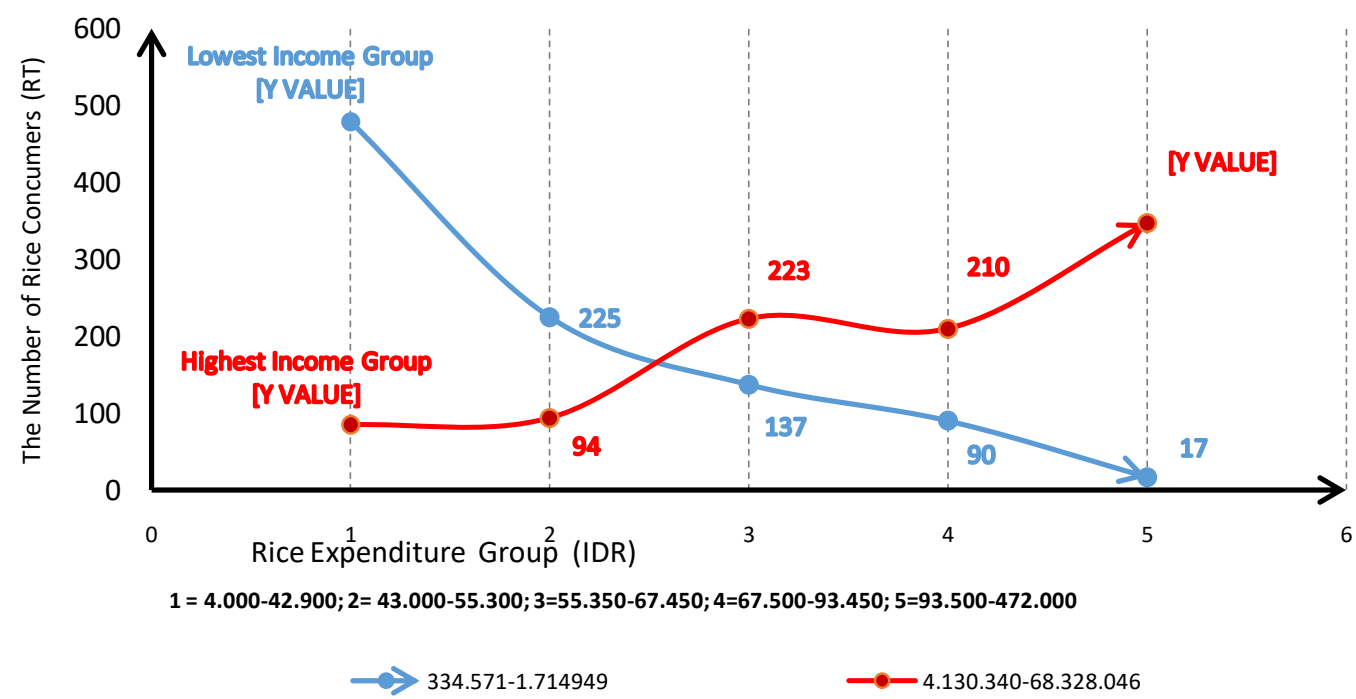

Figure 1 - Household Rice Consumption Expenditures Group according to the Highest and Lowest Earning Household Groups ( $=4.716)$

Cigarette commodity expenditure the second-largest household expenditure after rice consumption is traced to 3.213 households. Compared to the group with the highest rice expenditure, the highest cigarette consumption expenditure group varies greater and the mean is higher. A signs that households with the highest cigarette consumption spend more on cigarette consumption than rice consumption. 


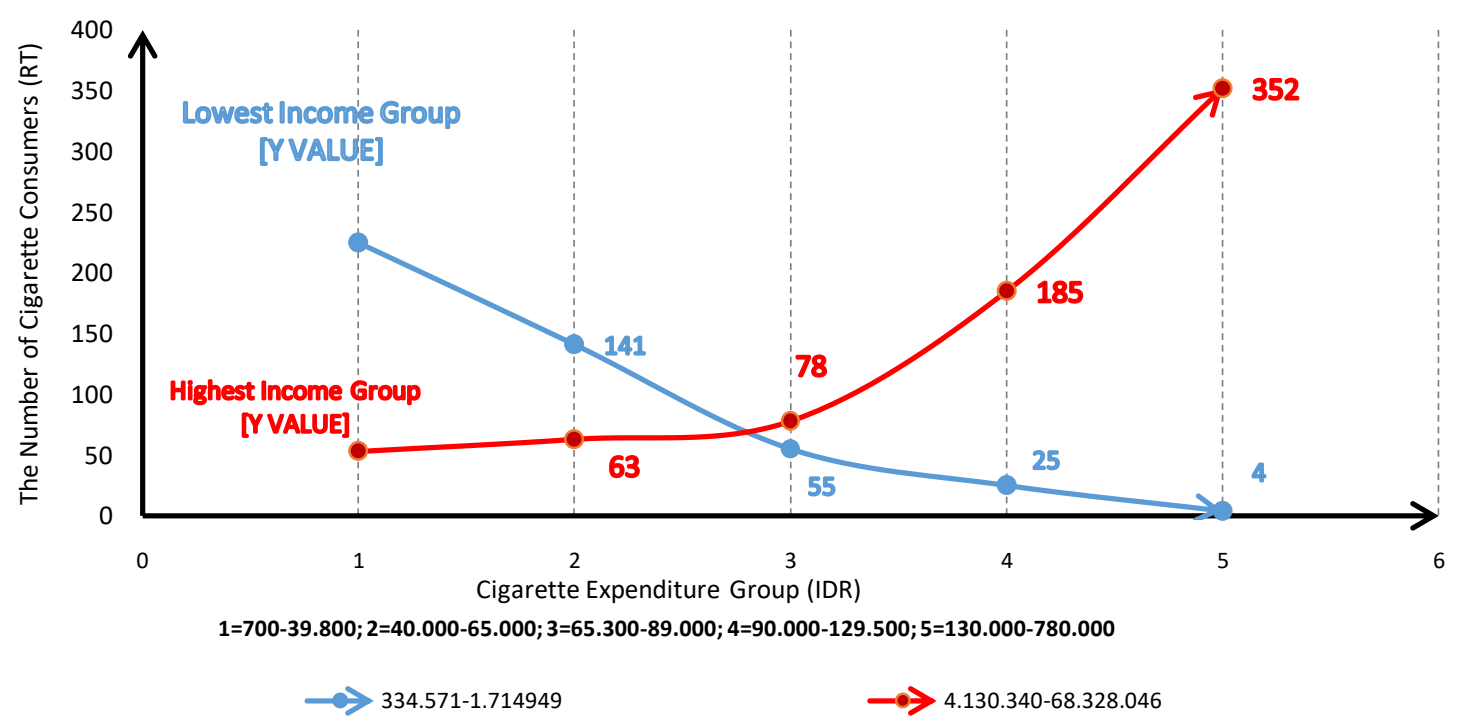

Figure 2 - Group of Household Cigarette Consumption Expenditures by Highest and Lowest Income Groups ( $\mathrm{N}=3.213$ )

Cigarette consumption characterized by cigarette expenditure tends to increase more and more as income increases, as evidenced by the distribution of households with the highest income groups getting greater in the third to fifth consumption expenditure groups with a proportion of 57 percent, 88 percent, and 99 percent. This distribution marks the increasing number of households that consume cigarettes with a greater amount of expenditure, even the biggest change in the number of households with the highest cigarette consumption expenditure compared to other expenditure groups (Figure 2).

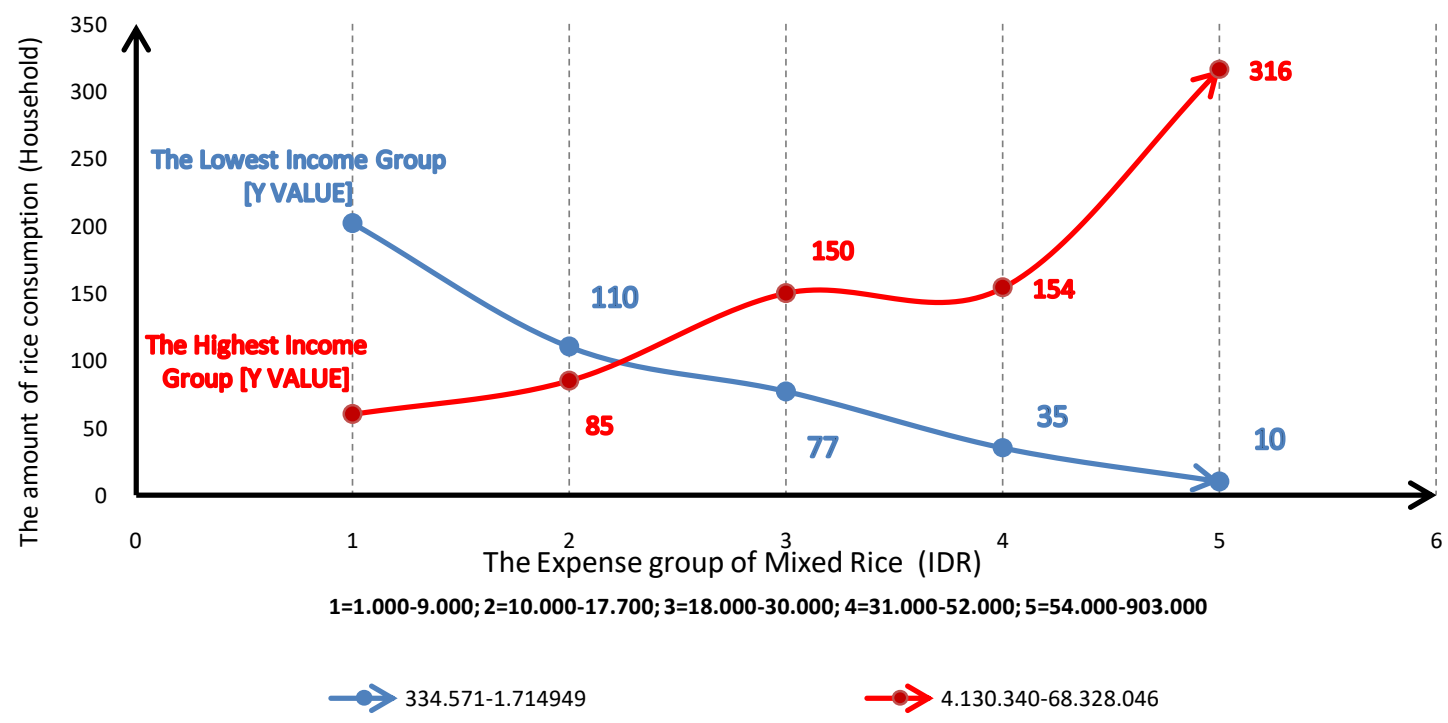

Figure 3 - The Expense Group of Household Mixed Rice consumption according to the Highest and Lowest Income Groups ( $=3150)$

The third commodity that has a major role in the expense of the largest food consumption is themixed rice which is detected through 3150 households. This commodity consumption has the same tendency as the previous two commodities. The expense of mixed rice increased with the increase in income as shown in Figure 3, but there was little difference in the third group with expense of IDR. 18,000.00 - IDR.30,000.00. As with rice consumption, very large differences in the number of households occur between the lowest- 
highest income groups and tend to be sensitive to income as indicated by the distribution of households which tends to be increasingly dominated by those with high income of $66 \%$ in the third expense group, $82 \%$ in the fourth group and $97 \%$ in the fifth group.

In the highest income group, the consumption of mixed rice is getting bigger and increasing sharply. The expense of Mean ranges from IDR.119,200.00 which is greater than the expense on rice commodities, being an initial marker of fulfilling household food consumption in the high income group in rural areas carried out through the consumption of mixed rice - a food product produced by a businessmen.

The fourth commodity that has a role in the largest food consumption expense is fish consumption expense with the number of households issuing financing for this consumption is 3488 households. Fish consumption expense in the household group with the largest expense varies between IDR. 36,000.00 to IDR. 280,000.00. This variation is the widest expense range of the other groups. In the highest expense group, the mean expense is around Rp. 53,600.00, indicates that the amount of fish consumption expense was half of the expense on mixed rice.

This commodity consumption pattern is almost no different from previous commodity consumption, has a similar pattern that is sensitive to income, as shown in Figure 4. This finding is still consistent with Recalis R.H. and Salas J.M.I. (2008); Sethi N. and Pradhan H.K. (2012); M.Fasoranti (2014); and Ahmad, A. et al (2017).

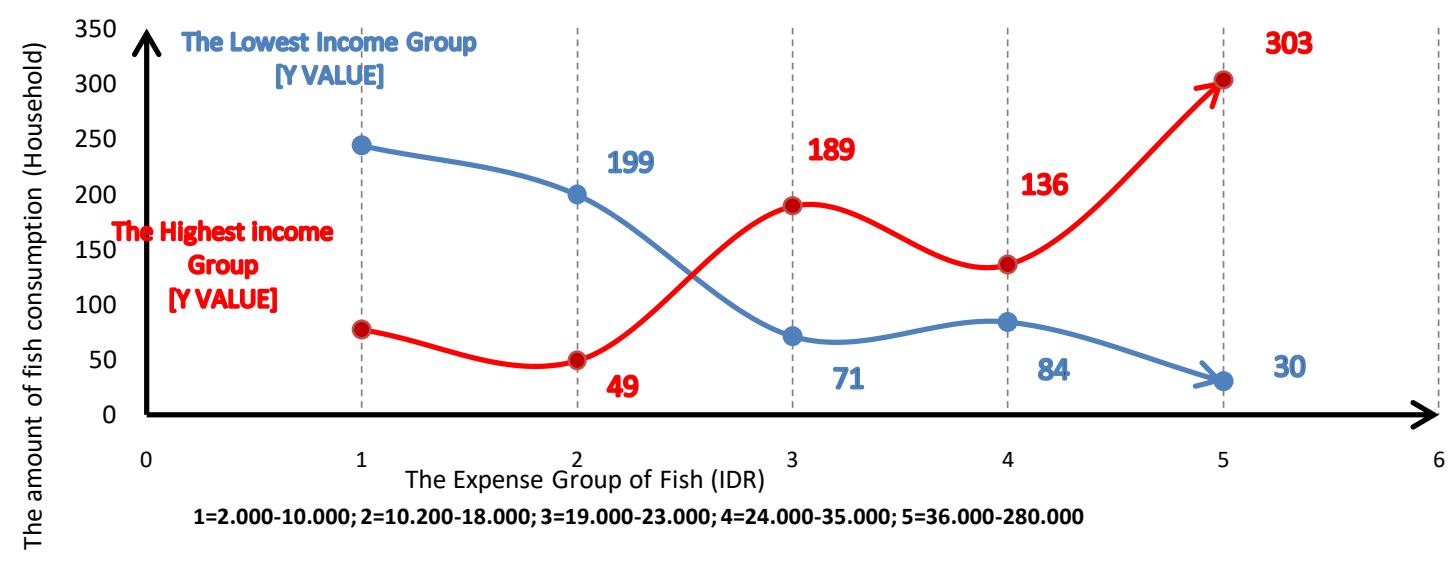

$\rightarrow 334.571-1.714949$

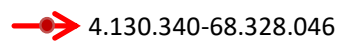

Figure 4 - The Expense Group of Household Fish consumption according to the Highest and Lowest Income Groups ( $=3488)$

The last commodity in food consumption expenseis the largest sugar expense, there are 4716 households that are detected as having this commodity expense. Like the previous commodity, consumption expense forsugar vary higher in the largest 20 percent expense group. Expense range from IDR.15,000.00 to IDR. 66,000.00 with a mean of around is IDR. $20,100.00$ indicates that this commodity is still accessible and a necessity for many households.

Using the lowest and highest income groups as shown in Figure 5. Consumption of sugar tends to increase with increasing income, but this pattern of consumption expense is relatively different from the previous four commodities. Household distribution begin to be dominated by those with the highest income after the third expense groupas in the previous four commoditiesin the fourth group with an expense of IDR. 12,000.00 to IDR. 14,800.00. The highest proportion of those with the highest income is $67 \%$ in the fourth group and $94 \%$ in the fifth group. In the group of highest consumption expense the change in the number of households becomes very large, marking this commodity as being consumed more by those with the highest income and vice versa although it is essential but this commodity is limited by the lowest income households. This consumption pattern is consistent with the results of 
Recalis R.H. and Salas J.M.I. (2008); Sethi N. and Pradhan H.K. (2012); M. Fasoranti (2014); and Ahmad et al (2017).

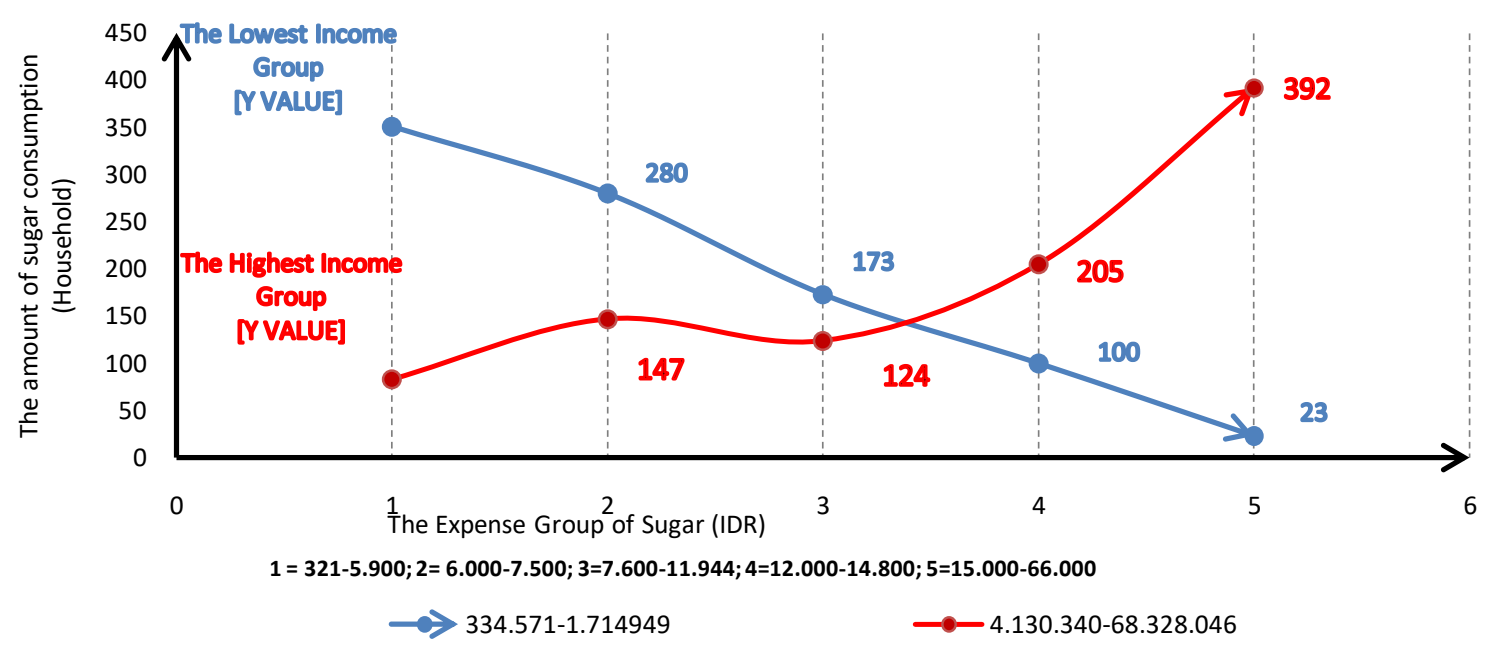

Figure 4 - The Expense Group of Household Sugar consumption according to the Highest and Lowest Income Groups ( $\mathrm{N}=3488)$

\section{CONCLUSION}

Consumption of rural households in Central Sulawesi is dominated by 20 types of commodities which are divided into 8 types of food commodities and 12 types of non-food commodities. The eight types of dominant commodities that represent food consumption are: (1) Rice; (2) Fish; (3) Chillies (4) Sugar(5) Traditional cakes(6) Mixed rice(7) Instant drinks and (8) cigarettes.

Subsequently identified through the large consumption expense, the five most food commodities in rural households are: (1) Rice; (2) cigarettes; (3) Mixed Rice; (4) Fish; (5) Sugar. The fifth types of food commodities, four of which are commodities to meet basic needs. The rest, cigarettes are one non-essential commodity that has the most consumption in rural areas.

Although there was a tendency for consistency between consumption expense and income through a cross table - five expense groups for each commodity and five household landing groups - mainly comparing the lowest and highest income to detect spending patterns. But this method is limited to the disclosure of consistency through its distribution, namely the frequency found in each category. For this reason, it is suggested that further efforts to ensure the interrelationship between various groups of consumption expense and income groups should proceed to test the hypothesis through the chi square analysis.

Detected the five of the most common household consumption commodities in rural areas consisting of four essential consumption, namely (1) Rice (2) Fish (3) Mixed rice and (4) Sugar. It should receive government attention in distribution policies without creating price distortions, so the households can accesswithout experiencing price constraints.

\section{REFERENCES}

1. Ahmad, Ahfandi., Rahmadanih, dan Ali, M. Saleh S. 2017. Patterns of Food Consumption and Production of Mountainous Community in Sinjai District, South Sulawesi Province, Indonesia. International Journal of Agriculture System (IJAS). Volume 5 Issue 1 June. Diperoleh dari https://www.researchgate.net/publication/318122299_Patterns_of_Food_Consumption_a nd_Production_of_Mountainous_Community_in_Sinjai_District_South_Sulawesi_Provinc e_Indonesia 
2. Anshori M dan Iswati S. 2017. Metodologi Penelitian Kuantitatif. Surabaya: Airlangga University Press.

3. Arikunto, S. 2013. ProsedurPenelitian: Suatu Pendekatan Praktik. Jakarta: Rineka Cipta.

4. Bungin, B. 2017. Metode Penelitian Kuantitatif: Komunikasi, Ekonomi, dan Kebijakan Publik, serta ilmu sosial lainnya. Edisi 2. Jakarta: Kencana.

5. BPS, 2017. Provinsi Sulawesi Tengah Dalam Angka. Katalog 1102001.72

6. BPS. 2017. Data Mikro, Modul Konsumsi Rumah Tangga Di Sulawesi Tengah.

7. Caron, Justin dan Fally, Thibault. 2018. Per Capita Income, Consumption Patterns, and CO2 Emissions. Papers conference and seminar. (on-line) diperoleh dari https://are.berkeley.edu/ fally/Papers/CO2paper.pdf

8. Lee, Seonglim., Sohn, Sang-Hee., Rhee, Eunyoung., G. Lee, Yoon., Zan, Hua. 2014. Consumption patterns and economic status of older households in the United States. Statistics Monthly Labor Review. U.S. Bureau of Labor. (on-line) diperoleh dari https://www.bls.gov/opub/mlr/2014/article/pdf/consumption-patterns-and-economicstatus-of-older-households.pdf

9. Marpaung, Harum. M. 2006. Pola Konsumsi Masyarakat: Profil Perilaku Beli Konsumen D.I. Yogyakarta. E-Jurnal Fenomena: vol. 4 No. 2. ISSN: 1693-4296. Direktorat Penelitian dan Pengabdian Masyarakat Universitas Islam Indonesia. Yogyakarta.

10. M. Fasoranti Mary. 2014. The Determinants of Consumption Pattern Among Rural Dwellers of Ondo State Case Study of Akoko North west Local Government. European Scientific Journal.

11. Nicholson, W. 2005. Microeconomic Theory: Basic Principles And Extension. 9th Edition. Ohio: South-Western, Thomson Corporation.

12. Purwaningsih, Y., Hartono, S., Masyhuri, Mulyo, J.H. 2010. Analisis Pola Pengeluaran Rumah Tangga menurut Tingkat Ketahanan Pangan di Provinsi Jawa Tengah. Jurnal Ekonomi Pembangunan, Volume 11, Nomor 2, Desember 2010, hlm.236-253.

13. Racelis, Rachel H. dan lan Salas, J.M. 2008. Have Lifecycle Consumption and Income Patterns in the Philippines. Discussion Paper Series No. 2008-11. Philippine Institute for Development Studies. (on-line) diperoleh dari https://www.ntaccounts.org/doc/repository/RS2008b.pdf

14. Salvatore, Dominick. 2006. Mikroekonomi: Schaum Outlines, edisikeempat. Terjemahan: Rudy S dan Haris M. Jakarta: Erlangga.

15. Sayekti, A. Ayiek Sih. 2009.Pola Konsumsi Pangan Rumah Tangga di Wilayah Historis Pangan Beras dan Non Beras di Indonesia. Fakultas Pertanian, Instiper, Yogyakarta. Hal. 201-218.

16. Sethi, Narayan dan Pradhan, Hemanta Kumar. 2012. The Patterns of Consumption Expenditure in Rural Households of Western of India: an Engel Ratio Analysis. OIDA International Journal of Sustainable Development. Ontario International Development Agency, Canada ISSN 1923-6654 (print) ISSN 1923-6662 (online) diperoleh dari www.oidaijsd.com http://www.ssrn.com/link/OIDA-Intl-Journal-Sustainable-Dev.html

17. Sharma, R., Trung Thanh Nguyen., dan Grote, Ulrike. 2018. Changing Consumption Patterns-Drivers and the Environmental Impact. Sustainability, 10, 4190. (on-line) diperoleh dari https://www.mdpi.com/2071-1050/10/11/4190/pdf/1

18. Sugiyono. 2011. Metode Penelitiaan Kuantitatif, Kualitatif, dan R \& D. Cetakan ke-13. Bandung: Alfabeta.

19. Zhu, Di. 2011. Consumption patterns of the middle class in contemporary China: a case study in Beijing. Journal Sustainable Development. (on-line) diperoleh dari https://www.research.manchester.ac.uk/portal/files/54507982/full_text.pdf 